研究課題別評価

1. 研究課題名：細胞運動制御の単分子スペックル法による総括的解析

2. 研究者氏名：渡邊 直樹

3. 研究の狙い:

細胞の形態変化や運動は、細胞が生体の機能を支えるうえでの重要な過程の1つである。 細胞質膜下に発達するアクチン線維は、構造を支持する足場を提供するのみならず、絶え間 ない改変を繰り返し、細胞伸展縁ではアクチン重合が細胞質膜を押し出すための動力を発生 している。このアクチン線維の重合·脱重合を捉えるために、蛍光アクチンを生細胞内で 1 分 子ごとに可視化し、細胞内アクチンとの共重合を捉える「蛍光単分子スペックル法」を開発し た。この手法をもとに、細胞伸展縁ではアクチン線維は先端部のみならず、そこから離れた起 点より盛んに重合すること、重合後数秒以内に脱重合を開始することを解明した ( Science 295:1083-1086 (2002))。この単分子スペックル法をアクチン制御分子にも応用することで、細 胞伸展におけるアクチン重合、分解の各経路の役割を解明する。

4. 研究結果:

(1)私が以前、低分子量 $G$ 蛋白質 Rho の標的分子として単離·クローニングした $m D i a 1$ は、細胞 質分裂や細胞極性形成に重要な Formin ファミリ一蛋白質の1員である。近年、Formin ファミリー が試験管内でアクチン核化を加速し、アクチン線維の伸長端に結合することが報告された。今回、 mDia1 を単分子スペックル法によって生細胞内で観察したところ、数十マイクロンの距離を毎秒 2.0 マイクロメーターで分子移動することを見出した。その移動は微小管とは無関係で、アクチン重 合、脱重合を阻害する3種の薬で停止した。その停止様式はアクチン線維の伸長速度の変化と一 致した。また、顕微鏡下、ミオシン非存在下にて mDia1 は重合をつづけるアクチン伸長端に会合し た。これらのデータは、mDia1 は重合するアクチンの重合端に結合しながらプロセッシヴに移動す ることを示す。この発見はモ一タ一蛋白質以外で長距離を移動する分子機構が存在することを、 しかも生細胞内で直接明らかにするものである。（2）細胞伸展部分の葉状突起における主要な アクチン線維端結合分子である、Arp2/3 複合体とキャッピングプロテインの細胞内での分子キネ ティクスデータを得た。用いた標識体の忠実性を証明するため、キャッピングプロテインに関して は、GFP 標識体のヘテロダイマーのリコンビナントの生化学的解析を行い、アクチン反矢じり端に $1.3 \mathrm{nM}$ の野生型に近い解離定数で結合することを確認した。Arp2/3 複合体に関しては、抗体を 作製し内在性の分子と標識体の局在の一致を確認した。得られた分子キネティクスから、数理モ デルを構築したところ、アクチン線維切断が恒常的に細胞内で起きることが高い確度で示された。 また、得られた定量化データからは、アクチン線維が切断されるだけではなく、再結合も起きること も示唆されており、細胞の形態を制御するためにアクチン線維が切断·再結合を繰り返し、再編成 されることが明らかにされた(投稿準備中)。（3）アクチンの求心性流動と細胞伸展端での線維 重合速度が葉状仮足先端では負に相関するのを見出した。用いた薬剤解析のデータを付加した 後、論文投稿の予定。

5. 自己評価:

生命科学の発展によって、多くの分子の構造やその遺伝子の表現系、分子間相互作用などが 
明らかにされてきた。アクチン細胞骨格系においては、精密な生化学的解析により、個々の分子 の性質の詳細が次々知られつつある。しかしながら、細胞1つをとつても、その内部は多数の分子 機構が絡み合う複雑系であり、個々の分子機構の性質がどうして細胞や個体の表現系につなが るのか、検証する手法の樹立が待たれている。今回のさきがけは、留学から帰国後間もないとき からスタートしたが、顕微鏡システムの構築など順調に進み、当初の目的であった、アクチン関連 蛋白質の蛍光単分子スペックル解析とそれによる細胞内アクチン線維代謝機構に新たな知見を 提示することができた。特にリコンビナント蛋白質を用いたGFP 標識体の生化学的性質の検証や、 細胞伸展部のアクチン生化学の数理モデル化による定量的解析など、他の類似の研究にはない 高い水準で、細胞内分子機構の性質の解明を遂行できたと思う。また、思いがけず、かつて自ら が単離した Formin ファミリー蛋白質の1つ、mDia1について、アクチン伸長端をプロセッシヴにキャ ップし、分子移動する性質を捉えることにも成功した。これらのことより、細胞内で分子機構がもつ 性質を直接捉えたり、細胞内生化学反応を定量的に解釈することを可能とする、一段と進んだ高 水準の研究に発展できたと考えている。

\section{6. 研究総括の見解:}

単分子スペックル法という斬新的な方法を導入し、アクチン線維の重合·脱重合に注目して、細 胞の運動機構を解明することを最終的な目標とした。

きわめて順調に研究を進渉させ、生細胞のアクチン線維の形成過程におけるアクチン分子の重 合·脱重合 (解離)の過程を解明し、期待通りの成果を収めた。また、既に新しい研究の展開に着 手しており、今後、一般的な細胞のほか、神経細胞の軸索伸長など細胞種に特異的な現象につ いても、解析を手掛けることで、従来にない新しい研究の展開も十分期待できる。

\section{7. 主な論文等：}

論文

1. Watanabe, N. and Higashida, C. (2004) Formins: Processive cappers of growing actin filaments. Exp. Cell Res. 301: 16-22.

2. Higashida, C., Miyoshi, T., Fujita, A., Oceguera-Yanez, F., Monypenny, J., Andou, Y., Narumiya, S. and Watanabe, N. (2004) Actin polymerization-driven molecular movement of mDia1 in living cells. Science 303(5666): 2007-2010

\section{和文総説·著書}

1. 東田知陽, 三好拓志, 渡邊直樹 (2005) 単分子スペックル顕微鏡によるアクチン生化学の 1 分子イメージング 蛋白質核酸酵素 第 50 巻 第 11 号 1436-1442

2. 渡邊直樹, 東田知陽, 三好拓志 (2005) アクチン重合が駆動する細胞運動の謎に挑む単分 子イメージング 生物物理 第 45 巻 第 6 号 292-296

3. 渡邊直樹 (2005) 細胞の中を分子でのぞくーLess is moreとSerendipity一 学術月報 第 58 巻 第 5 号 $389-391$

4. 渡邊直樹, 東田知陽 (2005) mDia1 とForminファミリー:アクチン伸長端をサーフインするプロ セッシブキャッパー 生化学 第 77 巻 第 2 号 136-140

5. 渡邊直樹 (2005) 単分子スペックル顕微鏡がみせるアクチン重合の細胞内分子キネティクス 日本薬理学雑誌 第 125 巻 第 2 号 103-108

6. 渡邊直樹, 東田知陽 (2005) アクチン重合駆動モーター“Forminファミリー” 化学と工業 第 
58 巻 第 2 号 150-152

7. 東田知陽, 渡邊直樹 (2004) アクチン重合端をサーフインするmDia1 実験医学 第 22 巻 第 15 号 2178-2180

8. 渡邊直樹, 東田知陽 (2004) 単分子スペックル顕微鏡法によるアクチン重合ダイナミクス解 析 わかる実験医学シリーズ 細胞骨格·運動がわかる 131-135

\section{招待講演}

1. システム神経生物学スプリングスクール(SNSS2004) 平成 16 年 3 月 22 日大阪府四条畷市 Probing molecular kinetics with single-molecule speckle microscopy: Actin turnover and mDia1, the actin polymerization-driven motor Naoki Watanabe

2. 第 18 回細胞生物学シンポジウム「細胞膜骨格のイメージング:一分子から個体まで」平成 16 年 11 月 25 日名古屋 Actin turnover and the long-range processive actin capping motion of $\mathrm{mDia} 1$ as revealed by single-molecule speckle microscopy Naoki Watanabe

3. Keystone Symposia, Cell Migration and Adhesion 平成 17 年 4 月 10 日米国ユタ州スノーバー ド Molecular Kinetics of the Arp 2/3 Complex and Capping Proteins at the Leading Edge

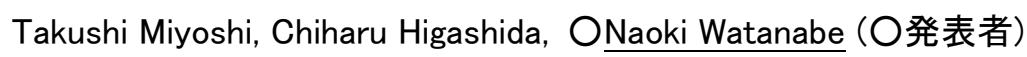

4. 第 58 回日本細胞生物学会大会 平成 17 年 6 月 17 日埼玉県大宮 Evidence of constitutive actin filament severing in lamellipodia Takushi Miyoshi, Chiharu Higashida, O Naoki Watanabe (O発表者)

5. 第 14 回日本バイオイメージング学会学術集会 平成 17 年 10 月 27 日東京 単分子イメージ ングによる細胞内アクチン重合機構の解析 渡邊直樹

\section{受賞}

平成 16 年度 (第 1 回) 日本学術振興会賞 